International Journal of English Literature and Social Sciences
Vol-6, Issue-1; Jan-Feb, 2021

\title{
Inclusiveness in Transnationalism and Cosmopolitanism
}

\author{
Pradeep Kumar Giri
}

Associate Professor, Tri-Chandra Multiple Campus, Tribhuvan University Kathmandu, Nepal

Received: 02 Nov 2020; Received in revised form: 06 Jan 2020; Accepted: 28 Jan 2021; Available online: 28 Feb 2021

(C)2021 The Author(s). Published by Infogain Publication. This is an open access article under the CC BY license

(https://creativecommons.org/licenses/by/4.0/).

\begin{abstract}
This article deals on transnationalism and cosmopolitanism as mutually inclusive ideals. Transnationalism believes in the transcendence of different types of boundaries that divides humans. Cosmopolitanism is an ideal, which stresses on the fact that all human beings belong to a single community based on a shared morality. Both the ideals stress that the whole world is borderless. These ideals believe in the view of transnational world-view. It means much inclusive to moral, economic, and political relationships between nations or individuals of different nations. The concept of cosmopolitanism is that all human beings, regardless of their citizenship, religion, political affiliation and other forms of boundaries, belong to a single community. Cosmopolitan theory considers the individual human being as the basic unit. The ideal of cosmopolitanism does not believe in any kind of border, rather it erases/transcends the borders created to narrow down and divide humans giving various names like nationality, culture, religion and so on which is similar to transnationalism.
\end{abstract}

Keywords-transnationalism, cosmopolitanism, border, community, humanity.

\section{OBJECTIVE}

The objective of this article is to study comparatively the two ideals transnationalism and cosmopolitanism showing the commonalities and prove them as mutually inclusive.

\section{METHODOLOGY}

In this research article, I use secondary materials-library, e-library, and internet-to explore the notion of transnationalism and cosmopolitanism. I explain, analyze, and verify that the two ideals are inclusive to each other. I do not use empirical method; nor do I conduct a field study, data collection, data analysis and interviews. Using analytical approach/qualitative method of research, I come to the conclusion with the finding of inclusiveness in the two notions as they stress on the crossing of all sorts of borders. This article integrates the ideas of theorists/writers like Ulrich Beck, Hans Kohn, Craig Calhoun, and Marcus
Aurelius. It makes use of their theoretical notions towards the concepts of transnationalism and cosmopolitanism.

\section{COSMOPOLITAN NOTION: CRITICAL THEORETICAL OVERVIEW}

The concept of cosmopolitanism was in existence even in ancient time giving a meaning of world citizenry: it was revived later in different times of history. Ulrich Beck writes in New Statesman:

The key idea for cosmopolitan manifesto is that there is a new dialectic of global and local questions, which do not fit into national politics. These questions are already part of the political agenda-in the localities and regions, in governments and public spheres both national and international. But only in a transnational framework can they be properly posed, debated and resolved. For this there has to 
be a reinvention of politics, a founding and grounding of the new political subject: that is- cosmopolitan parties. (29)

Cosmopolitanism does not believe in certain community or group of any kind having special ties and obligations to its members, rather it believes in equal treatment from the point of view of humanity. The global egalitarian goals of cosmopolitanism leave no space for nationalist and patriotic ideals. The history of cosmopolitanism finds its roots in the thought of the Ancient Greek Philosopher Diogenes, who lived around the time of Plato. Greece and Israel are the key sources of the Western legacy of universalism, humanism, reason, and liberty. Hans Kohn in The Idea of Nationalism: A Study in Its Origins and Background says, "It is significant that in antiquity only the two nationally conscious peoples developed a conscious cosmopolitanism and universalism" (36).

The term "cosmopolitanism" came from a double Greek root: the first component kosmos means "order," applied by Pythagoras to the universe in order to stress the orderliness of creation. The other is polis, the "city" or "city-state." "Polites" means "citizen." Thus, in ancient Greece a "kosmopolítes" was a "citizen of the world." The term came to indicate someone who considered the entire humankind as more meaningful than his or her own city, group, region, religion, or nation.

\section{INCLUSIVENESS IN TRANSNATIONALISM AND COSMOPOLITANISM}

Through conceptualization of a global citizen, we may arrive at a point where the local or national and global mind-sets meet. Writers like Salman Rushdie are engaged in "thinking and acting beyond the local." They have imagined collective rights and obligations in retreat from the nation, or have conceived of the center from the perspective of the margins. Talking about Goethe's concept on cosmopolitanism, Hans Kohn says that Goethe would agree, "The fatherland of the man who thinks without prejudice, who can rise above his time, is nowhere and everywhere" (qtd. in Kohn 414).

A cosmopolitan world would consist of a plurality of states that would use both regional and global consensus to gain greater bargaining power against opponents like nationalists who create boundaries. Cosmopolitanism shares the globally acceptable notion of human dignity and human rights preserved in international law. NGOs like "Amnesty International" and "Greenpeace" can work more effectively than the states on the global monitoring of human rights and environment since they enjoy a high level of legitimacy in the public sphere. Nearly all religious and philosophical systems demarcate humans from other living beings because of their monopolistic capability in speech and reason. The primary oppositional use of cosmopolitanism was to define humankind opposite to other living beings, as well as against all forms of "us"/ "them" dichotomies dividing humanity. Humankind constitutes a single community whose aim is peaceful coexistence for all individuals. The world is our fatherland over and above specific dissimilarities, including differences of religion, region, and culture and so on.

Service to fellow human beings is at the center of what it means to be cosmopolitan. Becoming a part of the Whole means being in relation to man as a citizen of that Whole which gives kindness toward humanity. In order to serve our fellow human beings, one has to transcend the personal desire and interest. To understand the idea of cosmopolitanism, Marcus Aurelius' saying deserves a mention:

One should continually think of the universe as one living being, with one substance and one soul. How all its actions derive from one impulse how all things together cause all that happens, and the nature of the resulting web and pattern of events. (33)

For a cosmopolitan a major goal in life is to become a virtuous world-citizen. This is possible to achieve by rejecting the desires of the flesh through Reason. Aurelius looks at death as a friend that brings comfort from the agony of fleshly living. He believes: "Death is a rest from the dichotomy of sense perception, from being jerked like a puppet by the strings of desire, from the mind's analysis and the service of the flesh." (54)

We can achieve the objectives of cosmopolitanism through cultivating a strong sense of democratic citizenship than through a global transplanting of the nation-state system. In For Love of Country, Amy Gutmann points out, "Democratic citizens have institutional means at their disposals those solitary individuals, or citizens of the world, do not. Some of those institutional mean are international in scope ... but even those tend to depend on the cooperation of sovereign societies for effective action" (71). Global democracy, thus, is best achieved not through some account of democratic global citizenship, but through the strengthening of local and nationally based democratic citizenship. 
Moral cosmopolitanism -- one of the various types - is not separable only in principle from institutional cosmopolitanism, but even in practice. The evidence suggests that we can hope to meet the ends of moral cosmopolitanism by not committing ourselves to a world government and the vague idea of global citizenship. The goals of moral cosmopolitanism are furthered by liberal nationalism. Certain practical difficulties are hard to overcome. Global justice may be implemented without a world state. Moral cosmopolitanism is a claim about the moral starting-point of cosmopolitan justice, whereas institutional cosmopolitanism is a claim about its institutional ending-point. Moreover, cosmopolitanism as a doctrine about justice speaks to the scope of justice, whereas cosmopolitanism as a doctrine about culture speaks to the content of justice. However, these different features of various types of cosmopolitanism are clearly and closely interrelated.

Politically, cosmopolitanism must be distinguished from humanism. Humanism is about universal human values, what we now call human rights. Cosmopolitanism combines humanism with a celebration of human diversity. In Political Writings from which the political meaning is derived, Kant describes a world of nation-states in which cosmopolitan right overrides sovereignty. Kant says that, the condition for perpetual peace is that cosmopolitan right be confined to the right of hospitality. What he means by this is treating strangers with dignity. Kant, writing at the end of the eighteenth century, was opposed to colonialism; he criticized those natives who maltreated their European visitors.

One can migrate out of choice not through pressure and choose to respect some traditions and not others. A cosmopolitan is free to choose the place where he or she lives and the practices in which they take part. A cosmopolitan politics is one, which insists both on global guarantees for human rights and on a global strategy for promoting the survival of cultures. For example, what makes Kathmandu, capital city of Nepal, such a vibrant place is precisely the fact that different cultures have survived side by side for so long: the temple, the mosque, the church, and the stupas are all within a few kilometers of each other. This shows the unity among diverse religious nations is possible because of the faith in the principle of coexistence, and inclusivity. Such diversity makes a cosmopolitan feel proud.

cosmopolitan respects different practices and rejoices at the fact that they can co-exist. Anthony D. Smith, in Nations and Nationalism in a Global Era argues that a timeless global culture answers no living needs. According to him, "Memory is central to identity. It strikes no chord among the vast masses of people divided into their habitual communities of class, gender, region, religion and culture" (24). As a cosmopolitan practice, fire fighters and policemen risk their lives to save other people, whatever their nationality is. Defending human rights is different from national wars in which people are willing not only to risk their lives but also to kill for their nations and to destroy their enemies. Cosmopolitanism, culture and global distributive justice are closely interrelated. Cosmopolitan justice, in short, is justice without borders. Cosmopolitanism as a doctrine about justice holds that our principle of distribution ought to apply to all individuals globally and not be restricted and shaped by national boundaries. Cosmopolitan distributive justice ignores membership in national culture or national group. The cosmopolitan notion of global distributive justice considers cosmopolitanism as a doctrine about justice. It holds that our principles of distribution ought to apply to all individuals globally, and not be restricted and shaped by national boundaries. This idea of justice is independent of cosmopolitanism understood as a doctrine about culture. There is no necessary correlation between this view of cosmopolitanism and cosmopolitan justice.

Cosmopolitan distributive justice, if fundamentally understood, says nothing about the value or disvalue of membership in a national culture. Distributive justice, therefore, is chiefly concerned with how resources and wealth are to be fairly allocated, and can remain neutral about the separate issue of culture and individual freedom. The ideals of cosmopolitan justice cannot be realized unless the adoption of the cosmopolitan view about culture. Cultural membership is important and that would force one to support other claims. For instance, one has special obligations to fellow members of the culture in which he/she belongs to, which are in opposition to the ideals of cosmopolitan global justice.

However, as John Rawls opines, humanitarian assistance cannot narrow down the gap between poor and rich. For example, mutual assistance among peoples in times of draught and famine is not only needed but it is of great significance if understood from humanitarian perspective. Cosmopolitans like Rawls have made attempt to show the importance of transcending beyond the borders of the state to include the world as a whole to make the distributive justice at the global level. Rawls expresses this idea in A Theory of Justice. He opines that principles of justice should apply 
between individuals across societies and not just within the borders of a single nation/society. Kant (1724-1804), a German philosopher, insists on a world government that is parallel to his stress on individual selfdetermination. Kant pledges for the abolition of national jurisdictions and their replacement by a universally applicable law. His project of perpetual peace was to be achieved under the support of an international government. The rise of internationalism--a belief in the need for nations to work together in a friendly spirit--as a distinctive concept has also been considered to the emergence of the working class as a historical actor. In the nineteenth century, the working class was torn between national identification and internationalism. The first usage of the term "internationalist" comes from the members of the First International Association of Workingmen, in London under the guidance of Karl Marx, while the idea of an "international solidarity among the proletarians of the world" dates back to Marx's and Engel's Communist Manifesto (1848).

Earlier, Cosmopolitanism was understood as a reaction against the privileging of the local city, class or religious sect having the interest only of its own. Cosmopolitans still depend on the locals in order to be able to conceive themselves as cosmopolitans and to be identified as such. Hence, cosmopolitanism can join itself with, and be opposed to, both localism and nationalism. Nationalism can find valid allies in both cosmopolitanism and localism. Cosmopolitan thinkers desire for a world organization in which universal values are protected and enforced. Consequently, the idea of a supranational i.e. supra -state organization is not only deeply related to the prevalence of universal moral principles, but the former's legitimacy is based on the internal acceptance and commitment to the latter. A definite cosmopolitan agenda can be pursued by encompassing the human variety of local, national and universal ideals. Historically, the "cosmopolitan," was conceived of as the antithesis to the "provincial." This concept subsequently functioned as a moralizing category for enlightened individuals at home in the urban centers and metropolises of the world. It marked the "citizen of the world" who was civilized and capable of fulfilling his duty as a rational citizen.

Julia Kristeva, in her Strangers to Ourselves, sketches a Eurocentric path of events of the history of the cosmopolitan, from St. Paul's vision of a multi-ethnic Christianity to the "citizen of the world" of the European enlightenment (164).
The nature of today's cosmopolitanism is multifaceted with its multiplicity of cultures, religions, and subcultures. The question is what are the qualities of such a "citizen of the world?" Cosmopolitanism emerges, as Anthony Kwame Appiah in Cosmopolitanism: Ethics in a World of Strangers observes, "with the simple idea that in the human community, as in national communities, we need to develop habits of coexistence, of 'conversation' in its older meaning, of living together, association" (xix). What Appiah suggests here is a fundamental change not only in the conceptual and legal framework but also in the existential modality in which people live in this world.

In many ways, a cosmopolitan is almost the same as a multilingual person. Cosmopolitanism does not simply call for rules of coexistence; it further requires of cosmopolitans the ability to move in a variety of cultures. Language reflects one's cultural identity and cultural codes as they can be acquired and are not mutually exclusive. A cosmopolitan is someone who belongs to and is fluent in the codes of multiple cultures. More to the point, multiculturalism and cosmopolitanism are much a matter of multiple belonging. One can raise a question, what does it take to be cosmopolitan? A cosmopolitan displays individuality and autonomy in the construction of personal identity, but at the same time rejects isolation to live in a social world, a world of cosmopolitans. This description of the world of cosmopolitans echoes Derrida's definition of the "democracy to come" as "[letting] singular beings (anyone) 'live together"' (qtd. in Park 7).

Kristeva, in her Strangers to Ourselves, shows how throughout Europe's path towards a cosmopolitan society, religious traditions have been home to members of a plurality of nationalities and ethnicities, while nations have included religious diversity. The internal difference--the recognition that communities are not unified but diverse, and as individuals share similarities with persons on the other side of the artificially constructed boundaries of national, religious, and personal identities- is experienced as what Sigmund Freud calls the "uncanny" and Kristeva, "our own foreignness" (169). Cosmopolitanism envisions a "paradoxical community," which, in Kristeva's words, "is made up of foreigners who are reconciled with themselves to the extent that they recognize themselves as foreigners" (195).

\section{CONCLUSION: TRANSNATIONALISM AND COSMOPOLITANISM OPPOSE TO LOCALISM}


Contrary to localism, cosmopolitanism and transnationalism stress on mutual inclusion to eliminate the artificial barriers between cultures and to indicate that communities and even selves are not homogenous. From a cosmopolitan perspective, it does not need to relate to other positions and identities in terms of identity and difference. Consequently, the study of philosophical positions need not be a matter of mere agreement or disagreement, but can become a search for similarities and differences that leads finally to understanding a multiplicity of positions. Inclusion becomes an important moral principle. Therefore, the characteristics of a cosmopolitan are familiarity with a multiplicity of cultural codes and the ability to be a citizen of the world in a paradoxical world.

In brief, cosmopolitanism and transnationalism are mutually compatible. Both of them break down the parochial idea of nation-state; they believe not in diversity but in uniformity, the local as well as the global. The global economy is both local and transnational. Both the cosmopolitans and transnationalists aspire to operate, as a bridge between two worlds and thus their goal is a unifying one. Bearing the awareness of one's own national identity, one can feel the notion of a global citizen and his or her global consciousness as the sum total of all existing ethnic, national or cultural identities.

\section{REFERENCES}

[1] Appiah, Anthony Kwame. Cosmopolitanism: Ethics in a World of Strangers, W. W. Norton, 2006.

[2] Aurelius, Marcus. The Meditations of Aurelius. Trans. G. M. A. Grube. Hackett Publishing Co, 1983.

[3] Beck, Ulrich. "The Cosmopolitan Manifesto." New Statesman, 1998, p. 29.

[4] Gutmann, A. "Democratic Citizenship." For Love of Country, Ed. J. Cohen. Beacon Press, 1996, pp. 66-71.

[5] Kant, Immanuel. "Perpetual Peace: A Philosophical Sketch." Political Writings Cambridge UP, 1991.

[6] Kohn, Hans. The Idea of Nationalism: A Study in Its Origins and Background. Macmillan, 1944.

[7] Kristeva, Julia. Strangers to Ourselves. Trans. Leon S. Roudiez, Columbia UP, 1991.

[8] Park, Jin Y. "Introduction: Rethinking Philosophy in a Time of Globalization." Comparative Political Theory and CrossCultural Philosophy: Essays in Honor of Hwa Yol Jung, Ed. Jin Y. Park, Rowman and Littlefield, 2009.

[9] Rawls, John. A Theory of Justice. Harvard UP, 1971.

[10] Smith, Anthony D. Nations and Nationalism in a Global Era, Polity, 1995. 